International Journal of Engineering \& Technology, $7(4.38)(2018) 832-836$
International Journal of Engineering \& Technology
WPC
Website: $w w w . s c i e n c e p u b c o . c o m / i n d e x . p h p / I J E T$
Research paper

\title{
Hypermarket Brand Extension Products and Service Experience
}

\author{
Hasliza Hassan*1, Muhammad Sabbir Rahman², Abu Bakar Sade ${ }^{3}$ \\ ${ }^{1}$ Faculty of Management, Multimedia University, Cyberjaya, Selangor, Malaysia \\ ${ }^{2}$ Department of Marketing and International Business, North South University, Dhaka, Bangladesh \\ ${ }^{3}$ Faculty of Business and Information Science, UCSI University, Kuala Lumpur, Malaysia \\ *Email Addresses: hasliza.hassan@mmu.edu.my
}

\begin{abstract}
This cross-sectional research examines the acceptance of consumers in hypermarket brand extension products and the enhancement of service experience being offered by hypermarkets in Malaysia by exploring the data collected through descriptive and cross-tabulation analyses. The majority of consumers in Malaysia accept the hypermarket brand extension products and service experience that are being offered by the hypermarkets. The consumer purchases and consumes the hypermarket brand extension products and service experience concurrently. The findings from this research offer a significant outcome in which the hypermarket retailers should provide a wider variety of products and service experience as an additional option for the consumers to choose. It is expected that this research will provide a breakthrough to determine how far hypermarkets could extend the retail brand in both products and services, and how this effort could be beneficial to the stakeholders. The concept of integrated marketing is explored further in this study by looking at the integration of products and services to deliver greater consumer value.
\end{abstract}

Keywords: Brand Extension, Experience, Hypermarket, Product, Service, Shopping.

\section{Introduction}

Hypermarkets are hubs from which one can purchase basic necessities for the household based on the self-service shopping concept. The hypermarket retailing concept was first brought to the Malaysian market in 1993. Since then, the emergence of hypermarkets in Malaysia as a modern self-service shopping retailing concept [1] has improved the entire retailing industry. According to recent statistics, the retailing industry in Malaysia is ranked third in the A.T. Kearney 2016 Global Retail Development Index (GRDI). One of the success factors is due to the development of the hypermarket retailing industry [2]. With the continuous high cost of living, more and more people, especially in urban areas, prefer to shop at hypermarkets for their basic daily necessities instead of going to shopping malls or small scale grocery shops near the residential areas to obtain better discounts. To cater to the needs of modern consumers, hypermarkets have been continuously enhancing the existing self-service shopping concept, thereby providing a better convenience shopping experience by offering a variety of additional service facilities.

Brand extension refers to the utilization of the hypermarket corporate retail brand name for the product brands that are placed on the shelves [3]. The majority of the hypermarket retail brands are considered to be well-known. Due to the recognition of the brand by consumers, nowadays, most hypermarkets are using the retail brand name in the product brand that is available on the shelves. Parallel to this, hypermarket retailers are also improving the available facilities to enhance the self-service shopping concept to provide a more convenient shopping experience. Hypermarkets are offering the extension of products and services through collab- oration with local small and medium enterprises that are willing to sell their product and offer services using the hypermarket retail brand as key supplier in the supply chain management [4]. There is a lack of research that looks at the hypermarket brand extension in products and service experience concurrently. As an initiative, this research is aimed to explore hypermarket brand extension in both products and service experience concurrently. Below are the research objectives of this study:

Research objective 1: To examine the acceptance of the hypermarket brand extension in products.

Research objective 2: To examine the acceptance of the hypermarket brand extension in service experience.

Research objective 3: To explore the association between the hypermarket brand extension in products and service experience.

\section{Hypermarket brand extension products}

Hypermarket brand extension product refers to the availability of products on the shelves that utilize the hypermarket retailing brand as the label. This branding strategy is also widely known as store brand [5] or private label brand [6]. Normally, the prices of wellknown manufacturer product brands are slightly more expensive than hypermarket brand extension products [7]. This definitely provides a chance for those consumers who would like to minimize their household expenses by purchasing hypermarket brand extension products instead of well-known manufacturer product brands [8]. The strategy that has being used by hypermarkets is in line with the continuous high cost of living, especially in urban areas, where the majority of consumers are looking for the best alternative to reduce their living expenses. Although the quality of hypermarket brand extension products is commonly perceived as 
inferior than well-known manufacturer brands, there are research findings proving that, nowadays, consumers believe that the quality is similar $[9 ; 10]$.

The uniqueness of hypermarket brand extension products is that the particular product brand is only available from the respective hypermarket retailer. For example, consumers can only purchase Tesco chili sauce at Tesco hypermarkets and it is impossible to purchase it at other hypermarket retailers, such as Giant, Econsave and Mydin. Hence, the availability of hypermarket brand extension products encourages consumers to continue to shop at a particular hypermarket retailer [11]. This research reveals the preference of consumers in Malaysia concerning hypermarket brand extension products by focusing on five product categories: 1) beverages, such as soda, coffee, tea and cordials; 2) carbohydrate products, such as rice, bread, noodles and spaghetti; 3) cereals, such as oats and cornflakes; 4) frozen foods, such as curry puffs, spring rolls, roti canai, doughnuts and pau; and 5) light food, such as cookies, chocolate and snacks. These five product categories are chosen since all of them are basic food and beverages that are normally consumed by the majority of people almost every day.

\section{Hypermarket service experience}

Hypermarkets were introduced as a place for consumers to purchase basic household necessities through the self-service shopping concept [12]. Nowadays, the existing service facilities that are provided by the majority of hypermarket retailers have been enhanced while maintaining the originality of the self-service concept. The improvement to the basic self-service shopping concept through a more convenient shopping experience, by providing better facilities within the hypermarket premises, has created a greater attraction for the consumers to shop and enjoy the shopping experience. Such enhancements include automatic price checkers, automatic check-out system, automatic money changer and facilities for children and disabled people. The improvements to the self-service shopping concept are to stimulate a positive shopping value to enhance consumer satisfaction [13].

The shopping experience could be enhanced through the availability of service facilities to create a better hypermarket atmosphere [14]. Understanding consumer acceptance of the available services is one of the paths to discover the shopping experience [15]. Since there are too many new self-service facilities that are available in hypermarkets, this research focuses on five categories of service: 1 1) automatic price checkers; 2) covered parking area; 3) food and beverage areas, such as cafeterias, food courts, kiosks and restaurants; 4) indoor facilities, such as seats, wheelchairs and washrooms; and 5) safety and security, such as CCTV, assistance from a security officer and baggage counter. These five categories of self-service are chosen because all of them are considered as additional facilities to enhance the original self-service shopping concept in hypermarkets.

\section{Methodology}

A cross-sectional research was conducted by focusing on consumers at selected hypermarket outlets as respondents. The data were collected from respondents through the distribution of a survey questionnaire. The survey questionnaire was distributed based on the stratified sampling of hypermarket distribution outlets throughout Malaysia by state. Additional data were collected from those states that have more hypermarket outlets to ensure the precision of the data sampling size for analysis. The questionnaire was set based on categorical data in which the respondents were required to choose whether they have experienced purchasing a particular category of hypermarket brand extension product and additional service facility being provided by the hypermarket retailers.
One thousand questionnaires were collected from the survey, and the collected questionnaires were screened manually and through the use of Statistical Package for Social Sciences (SPSS). A total of 790 questionnaires were used for descriptive and crosstabulation analyses. The number of sample data is suitable for this research analysis since the sampling meets the statistical requirement to represent the hypermarket consumer population in Malaysia $[16 ; 17]$. The acceptance of hypermarket brand extension in each category of product and service experience by the consumers is identified through descriptive analysis. An association relationship between hypermarket brand extension in each category of product and service experience is determined through crosstabulation analysis.

\section{Analyses and findings}

The statistical findings for the acceptance of hypermarket brand extension products are shown in table 1 . The majority of consumers purchase hypermarket brand extension products as basic necessities, which, indirectly, gives strong brand value to the hypermarket brand extension [18]

Table 1: The Acceptance of Hypermarket Brand Extension Products

\begin{tabular}{|c|c|c|}
\hline $\begin{array}{c}\text { Hypermarket Brand Extension } \\
\text { Products }\end{array}$ & $\begin{array}{c}\text { Number of } \\
\text { Acceptance }\end{array}$ & $\begin{array}{c}\text { Percentage of } \\
\text { Acceptance }\end{array}$ \\
\hline Beverages & 581 & $73.54 \%$ \\
\hline Carbohydrate products & 526 & $66.58 \%$ \\
\hline Cereals & 457 & $57.85 \%$ \\
\hline Frozen foods & 490 & $62.03 \%$ \\
\hline Light food & 562 & $71.14 \%$ \\
\hline Total respondents & $\mathbf{7 9 0}$ & $\mathbf{1 0 0 . 0 0 \%}$ \\
\hline
\end{tabular}

The statistical findings for the acceptance of hypermarket service experience are shown in table 2. All five categories of service are considered as mostly consumed by the majority of the consumers. The findings from this analysis prove that the majority of consumers accept hypermarket brand extension in the service experience.

Table 2: The Acceptance of Hypermarket Service Experience

\begin{tabular}{|c|c|c|}
\hline Hypermarket Service Experiences & $\begin{array}{c}\text { Number of } \\
\text { Acceptance }\end{array}$ & $\begin{array}{c}\text { Percentage of } \\
\text { Acceptance }\end{array}$ \\
\hline Automatic price checker & 572 & $72.41 \%$ \\
\hline Covered parking area & 589 & $74.56 \%$ \\
\hline Food and beverages & 617 & $78.10 \%$ \\
\hline Indoor facilities & 626 & $79.24 \%$ \\
\hline Safety and security & 464 & $58.73 \%$ \\
\hline Total respondents & $\mathbf{7 9 0}$ & $\mathbf{1 0 0 . 0 0 \%}$ \\
\hline
\end{tabular}

Cross-tabulation analysis is used to examine the third research objective, which is, to explore the association between the hypermarket brand extension in products and service experience. The summary of the $\rho$-value for the cross-tabulation analysis between each category of hypermarket brand extension product and service experience is shown in table 3. According to the analysis, all categories of hypermarket brand extension in products are significantly associated with service experience $(\rho$-value $<0.05)$. This strongly proves that the majority of consumers purchase and consume both hypermarket brand extension in products and additional service facilities concurrently.

Table 3: Cross-Tabulation of Hypermarket Brand Extension Products and Service Experience

\begin{tabular}{|c|c|c|c|c|c|}
\hline $\begin{array}{c}\text { Cross- } \\
\text { Tabulation }\end{array}$ & 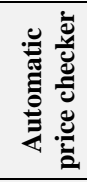 & 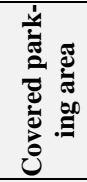 & 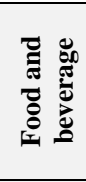 & 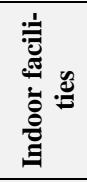 & 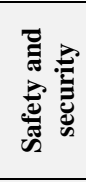 \\
\hline Beverages & 0.000 & 0.000 & 0.000 & 0.000 & 0.000 \\
\hline $\begin{array}{l}\text { Carbohydrate } \\
\text { products }\end{array}$ & 0.001 & 0.000 & 0.002 & 0.023 & 0.000 \\
\hline
\end{tabular}




\begin{tabular}{|c|c|c|c|c|c|}
\hline Cereals & 0.000 & 0.000 & 0.000 & 0.000 & 0.000 \\
\hline Frozen foods & 0.000 & 0.033 & 0.000 & 0.000 & 0.000 \\
\hline Light food & 0.000 & 0.000 & 0.000 & 0.008 & 0.000 \\
\hline
\end{tabular}

Note: The number in the cell represent $\rho$-value $<0.05$

\section{Discussion and contribution}

This research has found that the majority of the consumers purchased hypermarket brand extension products. The acceptance of consumers of hypermarket brand extension products has proven that consumers have used the products, which definitely enhances the brand experience and builds brand trust [19]. This findings is actually common to those countries that is under emerging economy [20]. The highest acceptance of brand extension products is for beverages $(73.54 \%)$, followed by light food $(71.14 \%)$, carbohydrate products $(66.58 \%)$ and frozen food $(62.03 \%)$. Only $57.85 \%$ of the respondents purchased hypermarket cereal brands Although the consumption percentage of hypermarket brand extension for cereals is the lowest among the product categories, the percentage still represents more than half of the total respondents.

There is also high acceptance of the newly enhanced selfservice facilities that are being offered by hypermarkets. These findings strongly support the importance of services in retailing where smiling alone is not sufficient to achieve service excellence [21]. The analysis of the results shows that most respondents consumed hypermarket services, such as indoor facilities (79.24\%), food and beverage areas $(78.10 \%)$, covered parking areas $(74.56 \%)$ and automatic price checkers $(72.41 \%)$. Only $58.73 \%$ of the respondents consumed safety and security in the hypermarket. Although the consumption percentage for safety and security is the lowest, it still represents more than half of the total respondents. It is still important for hypermarket retailers to look at the safety and security of the consumer while shopping at the hypermarket as an additional service facility that needs to be addressed. Any unintended scenarios that happen in the hypermarket outlet will affect the overall reputation of the corporate retail brand. Hence, precautions concerning issues that are related to the consumers are very important for hypermarkets to ensure that the reputation of their retail brands is continuously secure. The enhancement of shopping experience through additional service facilities will motivate the consumer to shop at that particular hypermarket outlet.

Consumers do not go to the hypermarket just to purchase or consume either the product or service but to purchase and consume both products and services. This is proven through the crosstabulation analysis findings in this research. Therefore, both the product and service should be emphasized in a parallel way [22] Indirectly, this means that those consumers who come and experience the shopping environment will definitely at least purchase a product from that hypermarket and vice versa. A continuous effort to enhance the service should be taken since it will attract more consumers to not just consume the services but also to purchase the products as a main source of revenue for the hypermarket retailers. The availability of hypermarket brand extension products and the enhancement of the service experience will definitely provide an opportunity for consumers to purchase products at lower prices, and, at the same time, to have a convenient shopping experience. The pricing and convenience factors will definitely attract more consumers to a particular hypermarket [23].

\section{Limitations and further studies}

Innovation management could have a considerable impact on hypermarkets $[24 ; 25]$, and is crucial in brand management for hypermarket growth and development [26]. The extension of hypermarket retail brands into products and service experience is also considered as part of the innovation in brand management. The scope of hypermarket brand extension in both products and services could always be enhanced to another level by a large number of diverse product categories, as well as through broad coverage of hypermarket service facilities. The scope of product categories can be extended by looking at other basic necessities, such as those for cooking, cleaning, stationery, electrical products and clothes. Parallel to this, the scope of the service categories can be extended by examining how sub-retailers within the hypermarket are able to enhance the consumer shopping experience. Further study can also be made by looking at the hypermarket ambience, such as music, store layout, service providers and facilities for disabled consumers.

Although much research has been made in hypermarket brand extensions for both products and services, it is still hard to find research focusing on both products and services concurrently. The findings of this research only focus on the current scenario in Malaysia. Although hypermarket brand extension has been widely accepted in developed countries, especially in Europe and Ameri$\mathrm{ca}$, as there has been a lack of research and findings in developing countries, further research is necessary in other developing countries. It would also be beneficial to make a comparison between the acceptance of hypermarket brand extension by consumers in developing and well-developed countries, and look at the possibilities of how far these two communities can assist each other to share the positive impact.

Currently, modern retailing in Malaysia is perceived as being saturated, especially in the capital city of Kuala Lumpur [2]. In line with this, the hypermarket retailing industry has been moving towards virtual hypermarket retailing. In developed countries, nowadays, consumers are using virtual hypermarket services through which almost all basic necessities - groceries, perishable foods, and frozen food - can be purchased online. This is known as self-service information technology (SSIT) in retailing [27]. The wave of SSIT in retailing has arrived in Asia and taking the market by storm [28]. Hypermarket retailers in Malaysia have been implementing the SSIT over the past few years. However, from general observation, it seems that in Malaysia many consumers still prefer to purchase fresh and perishable products from the physical hypermarket instead of purchasing through SSIT. Although there is a high possibility that virtual hypermarket operations will take over the physical hypermarket operations, for the time being, Malaysia is still considered to be a developing country that is still catching-up on the technology. The culture of information technology and communication savvy by the new generation is expected to stimulate the virtual hypermarket operations. An initiative to discover the acceptance of the consumer of the newly introduced technology as an additional shopping channel [29] will definitely add more knowledge to the hypermarket retailing field.

\section{Managerial implications}

Hypermarket retailers should always consider ways to extend the hypermarket retail brand into products as a way to attract more consumers. Due to a continuous increase in the cost of living, the majority of people, especially in urban areas, seem to have limited options to reduce their living expenses. One of the easiest options is by reducing their daily expenses on basic household necessities that can normally be purchased from hypermarkets. In line with this, it would be a good opportunity for the hypermarket retailers to cater to this target market. The demand for hypermarket brand extension in products is expected to increase and be stable since, currently, the majority of people purchase these products. With the high challenge to survive in terms of living costs, especially in urban areas, there is a possibility that more consumers will purchase hypermarket brand extension products within the next few years. The availability of hypermarket brand extension products has assisted consumers to purchase basic household necessities, especially groceries, at a lower price and in larger quantities to support their family. 
The enhancement of the service experience in hypermarkets has transformed the retailing concept to be almost on a par with that of shopping malls - this is because, currently, hypermarkets offer a similar modern shopping experience. Accordingly, those consumers who are on a very tight budget can bring their family to experience the modern shopping environment at the hypermarket instead of to a shopping mall. Most hypermarkets do not charge a fee, or, at the most, a minimal fee for the services that are being provided, whereas the majority of shopping malls require consumers to pay for almost all services based on usage. This creates a competitive edge for hypermarkets compared to shopping malls. In line with this, the availability of self-service information technology by the hypermarket extends the shopping convenience to the consumers from home.

It is crucial for hypermarkets to extend the retail brand into both products and service experience, since the majority of consumers consume the available products and services concurrently. Accordingly, the strategy to extend the hypermarket brand in both products and services is equally crucial to compete and sustain in a highly competitive retailing industry. Overall, hypermarkets are a part of the modern retailing industry and provide more flexibility to consumers to shop for household products, while, at the same time, they can enjoy the available services at a more affordable price. The capability of the hypermarket retailers to compete by offering lower prices and enhance the convenience as a shopping experience will create considerable momentum for the whole retailing industry in Malaysia.

\section{Conclusion}

The findings in this research support all three research objectives which are 1) to examine the acceptance of the hypermarket brand extension in products, 2) to examine the acceptance of the hypermarket brand extension in service experience and 3) to explore the association between the hypermarket brand extension in products and service experience. The first two research objectives were analysed using descriptive analysis while the third research objective was analysed using cross-tabulation analysis. The majority of consumers in Malaysia accept hypermarket brand extension products and the additional service experience that is currently available in most hypermarkets. The hypermarket brand extension products and service experience that are being offered has created a new market dimension to cater to the needs for middle and low income earners who constitute the main population in Malaysia. In line with this, the availability of hypermarket brand extension also provides an alternative for those high income earners who are price conscious to gain more value for their expenditure.

Since consumers are purchasing the hypermarket brand extension products and consuming services as part of the shopping experience concurrently, there is a need for the hypermarket retailers to emphasize both necessities. Hence, a continuous effort to strengthen the strategy to enhance the hypermarket brand extension into products and services is highly expected to change the retailing landscape to be more competitive. The huge momentum that has been created by the hypermarket retailers has drastically stimulated the development of the whole retailing industry due to the continuous innovation strategies that have been introduced. In line with the high cost of living, especially in urban areas, the availability of hypermarket retailers has empowered people to have a more affordable modern lifestyle. Hypermarket managers must therefore treat their value adding activities in terms of products and services in an integrative manner.

\section{References}

[1] Lee, C. (2004), Centre on regulation and competition: Working paper series, Competition Policy in Malaysia, Centre on Regulation and Competition, Vol. 68, pp. 1-29.
[2] Damodaran, R. (2016), Malaysia clinches 3rd position in 2016 global retail development index, New Straits Times Online.

[3] Keller, K.L. and Aaker, D.A. (1998), The impact of corporate marketing on a company's brand extensions, Corporate Reputation Review, Vol. 1, No. 4, pp. 356-378.

[4] Teller, C., Kotzab, H., Grant, D.B. and Holweg, C. (2016), The importance of key supplier relationship management in supply chains, International Journal of Retail \& Distribution Management, Vol. 44, No. 2, pp. 109-123.

[5] Kaswengi, J. and Diallo, M.F. (2015), Consumer choice of store brands across store formats: A panel data analysis under crisis periods, Journal of Retailing and Consumer Services, Vol. 23, pp. 7076.

[6] Beneke, J. and Carter, S. (2015), The development of a consumer value proposition of private label brands and the application thereof in a South African retail context, Journal of Retailing and Consumer Services, Vol. 25, pp. 22-35.

[7] Méndez, J.L., Oubina, J. and Rubio, N. (2008), Expert quality evaluation and price of store vs. manufacturer brands: An analysis of the Spanish mass market, Journal of Retailing and Consumer Services, Vol. 15, No. 3, pp. 144-155.

[8] Diallo, M.F. and Kaswengi, J. (2016), What drives store brand purchases during crisis periods? Evidence from panel data in four product categories, International Journal of Retail \& Distribution Management, Vol. 44, No. 3, pp. 301-319.

[9] Mayer, P. and Vambery, R.G. (2013), Unbranding: threat to brands, opportunity for generics and store brands, Journal of Consumer Marketing, Vol. 30, No. 2, pp. 140-149.

[10] Rossi, P., Borges, A. and Bakpayev, M. (2015), Private labels versus national brands: The effects of branding on sensory perceptions and purchase intentions, Journal of Retailing and Consumer Services, Vol. 27, pp. 74-79.

[11] Ngobo, P.V. (2011), Private label share, branding strategy and store loyalty, Journal of Retailing and Consumer Services, Vol. 18, No. 4 , pp. $259-270$

[12] Swoboda, B., Haelsig, F., Morschett, D. and Schramm-Klein, H. (2007), An intersector analysis of the relevance of service in building a strong retail brand, Managing Service Quality, Vol. 17, No. 4, pp. 428-448.

[13] Kesari, B. and Atulkar, S. (2016), Satisfaction of mall shoppers: A study on perceived utilitarian and hedonic shopping values, Journal of Retailing and Consumer Services, Vol. 31, pp. 22-31.

[14] Cottet, P., Lichtlé, M.C. and Plichon, V. (2006), The role of value in services: a study in a retail environment, Journal of Consumer Marketing, Vol. 23, No. 4, pp. 219-227.

[15] El Hedhli, K., Zourrig, H. and Chebat, J.C. (2016), Shopping wellbeing: Is it just a matter of pleasure or doing the task? The role of shopper's gender and self-congruity, Journal of Retailing and Consumer Services, Vol. 31, pp. 1-13.

[16] Awang, Z. (2012), Structural equation modeling using AMOS graphic, UiTM Press.

[17] Hair, J.F., Black, W.C., Babin, B.J. and Anderson, R.E. (2010), Multivariate data analysis: A Global Perspective, 7th Edition, Prentice Hall.

[18] Fornari, D., Fornari, E., Grandi, S. and Menegatti, M. (2016), Leading national brands facing store brands competition: Is price competitiveness the only thing that matters?, Journal of Retailing and Consumer Services, Vol. 30, pp. 234-241.

[19] Baumann, C., Hamin, H. and Chong, A. (2015), The role of brand exposure and experience on brand recall—Product durables vis-àvis FMCG, Journal of Retailing and Consumer Services, Vol. 23, pp. $21-31$.

[20] Sarkar, S., Sharma, D. and Kalro, A.D. (2016), Private label brands in an emerging economy: an exploratory study in India, International Journal of Retail \& Distribution Management, Vol. 44, No. 2, pp. 203-222.

[21] Andrzejewski, S.A. and Mooney, E.C. (2016), Service with a smile: Does the type of smile matter?, Journal of Retailing and Consumer Services, Vol. 29, pp. 135-141.

[22] Brun, A. and Castelli, C. (2008), Supply chain strategy in the fashion industry: Developing a portfolio model depending on product, retail channel and brand, International Journal of Production Economics, Vol. 116, No. 2, pp. 169-81.

[23] Farhangmehr, M., Marques, S. and Silva, J. (2001), Hypermarkets versus traditional retail stores-consumers' and retailers' perspectives in Braga: a case study, Journal of Retailing and Consumer services, Vol. 8, No. 4, pp. 189-198. 
[24] Pantano, E. (2016), Benefits and risks associated with time choice of innovating in retail settings, International Journal of Retail \& Distribution Management, Vol. 44, No. 1, pp. 58-70.

[25] Saran, A., Serviere, L. and Kalliny, M. (2009), Corporate culture, organizational dynamics and implementation of innovations: A conceptual framework, Asian Journal of Marketing, Vol. 3, No. 1, pp. 10-19.

[26] Liu, P.L. and Tsai, C.H (2010), The influence of innovation management on new product development performance in Taiwan's hitech industries, Research Journal of Business Management, Vol. 4, No. 1, pp. 31-40.

[27] Kallweit, K., Spreer, P. and Toporowski, W. (2014), Why do customers use self-service information technologies in retail? The mediating effect of perceived service quality, Journal of Retailing and Consumer Services, Vol. 21, No. 3, pp. 268-276.

[28] Shanmugam, M. (2016), Parkson's decline a sign of the times for retail stores, Business News, The Star Online.

[29] Bhatnagar, A. and Papatla, P. (2016), Increasing online sales by facilitating spillover shopping, Journal of Retailing and Consumer Services, Vol. 29, pp. 58-69. 